\title{
Diversity and Seasonal Changes in the Ichthyofauna of Rocky Tidal Pools from Praia Vermelha and São Roque, Santa Catarina
}

\author{
João P. Barreiros ${ }^{1 *}$, Áthila Bertoncini ${ }^{2}$, Leonardo Machado ${ }^{2}$, Maurício Hostim-Silva ${ }^{2}$ and \\ Ricardo Serrão Santos ${ }^{3}$ \\ 1 Universidade dos Açores; Departamento de Ciências Agrárias; 9701-851; jpedro@angra.uac.pt; Angra \\ do Heroísmo - Portugal. ${ }^{2}$ Universidade do Vale do Itajaí; Centro de Ciências Tecnológicas da Terra e do Mar; \\ apnea@uol.com.br; machado.lf@lycos.com; hostim@cttmar.univali.br; C.P. 360; 88032-202; Itajaí - SC - Brazil. \\ ${ }^{3}$ Universidade dos Açores; Departamento de Oceanografia e Pescas; ricardo@horta.uac.pt; 9901-862; Horta - \\ Portugal
}

\begin{abstract}
A survey of the tidal pool fish community was carried out between April 1998 and May 1999, at the beaches of Praia Vermelha (PV) and São Roque (SR), Santa Catarina, Brazil. The pool of PV was bigger and closer to the subtidal. Specimens were collected monthly at low tide, using quinaldine. In PV we collected 1287 fish belonging to 19 species and in SR 553 fish were caught corresponding to 11 species. In both pools, dominant species were Bathygobius soporator (Gobiidae), Abudefduf saxatilis (Pomacentridae), Parablennius pilicornis (Blenniidae), Gobiesox barbatulus (Gobiesocidae), Labrisomus nuchipinnis (Labrisomidae) and Epinephelus marginatus (Serranidae). Summer months had higher abundance and diversity values, and correspond to a recruitment season for both A. saxatilis and E. marginatus.
\end{abstract}

Key words: Ichthyofauna, rocky tidal pools, diversity, Santa Catarina, Brazil

\section{INTRODUCTION}

Shallow water fish communities have been studied in many parts of the world, especially in the IndoPacific (Prochazka et al., 1999) but also in the Atlantic (e.g Gibson, 1972; Jones and Clare, 1977; Arruda, 1979; Bennett and Griffiths, 1984; Mahon and Mahon, 1994; Santos et al., 1994; Rosa et al., 1997). Rocky tidepools have a high degree of environmental variability due to daily changes in hidrodinamism, tidal cycles (Fuji, 1988) and pressure from predators and competitors both from the subtidal and the terrestrial domain (Beja, 1995;
Gordon, 1998). Tidal pool fishes can be classified as residents and transients that live in these habitats for varied periods that can stretch from just a few days to years, while some species are just occasional visitors (Grossman, 1982; Gibson and Yoshiyama, 1999). Although the importance of tidepools for juvenile growth and reproduction is known to be very important (Crabtree and Dean, 1982; Rangeley and Kramer, 1995) the juveniles found in rocky tidepools belong, generally, to resident species (Prochazka, 1996; Willis and Roberts, 1996). As pointed out by Zacharias and Roff (2001), studies of intertidal habitats have been directed in three ways: i) identification of

\footnotetext{
${ }^{*}$ Author for correspondence
} 
recurring species assemblages; ii) characterization of biological communities and evaluation of the latitudinal gradient of diversity and iii) the influence of environmental variables in communities structure and diversity. In Brazil, studies on rocky intertidal pools are relatively scarce (see Almeida, 1973, 1983; Rosa et al., 1997) and non-existent for Santa Catarina State, which has a low abundance of tide pools.

\section{MATERIALS AND METHODS}

This study was carried out at the beaches of São Roque (SR) and Praia Vermelha (PV) $\left(27^{\circ} 15^{\prime} \mathrm{S}\right.$; $48^{\circ} 30^{\prime} \mathrm{W}$ ) (Fig. 1). For each site one tidepool was used. The tidepool from PV had an average area of $23 \mathrm{~m}^{2}$ and average depth of $17.5 \mathrm{~cm}$. Maximum depth at low-tide was $44 \mathrm{~cm}$ and the average distance to low-tide limit was $6 \mathrm{~m}$. In $\mathrm{SR}$, the average area was of $18.0 \mathrm{~m}^{2}$, average depth $12.5 \mathrm{~cm}$, maximum depth at low-tide $38 \mathrm{~cm}$ and average distance to low-tide limit $13 \mathrm{~m}$. Water temperature was measured with a digital thermometer, before each sampling and at the previous high tide.

Between April 1998 and May 1999, a monthly collection was made at each pool at daytime. Due to unfavourable weather conditions, no collections were made in SR in June and in September 1998. All fishes present in the pools were collected in each sample using the anaesthetic Quinaldine (20\% solution in acetone) in an approximate dosage of 10ppm (Gibson, 1967; 1999).

Spearman rank correlation and Sign test (z differences) were used for comparing both sites and test co-variations with physical data. Species richness was determined through the number of species present and the expected number of species in a sample of $\mathrm{n}$ individuals taken from the community with the rarefaction method as proposed by Magurran (1988). Diversity was measured with the Shannon $\left(H^{\prime}\right)$ index and evenness was determined with the index $\left(J^{\prime}\right)$ (Pielou, 1977; Ludwig and Reynolds, 1988). Percent similarity between samples was determined with the Jaccard index (Magurran, 1988). According to their use of tide pools, species were classified in three categories, following an adaptation of Gibson and Yoshiyama, 1999): i) residents - permanent residents, ii) transients - when spending part of their life cycles in tide pools or being frequent visitors and iii) occasional - when occurring sporadically in tide pools.

\section{RESULTS}

\section{Temperature}

Over the sampling period, temperature varied between $20^{\circ} \mathrm{C}$ (July - both sites) and $27^{\circ} \mathrm{C}$ (SR) to $28^{\circ} \mathrm{C}(\mathrm{PV})$ (December).

\section{Fish Assemblage}

In PV, 19 species were caught yielding 1287 fish weighing $4140.68 \mathrm{~g}$ (Table 1). This constituted an average of 4.66 fish $\mathrm{m}^{-2}$ and $14.95 \mathrm{~g} \mathrm{~m}^{-2}$. In SR 11 species occurred corresponding to a total of 553 fish and $1717.42 \mathrm{~g}$ (Table 2). This constituted an average of 2.56 fish $\mathrm{m}^{-2}$ and $7.95 \mathrm{~g} \mathrm{~m}^{-2}$. Over the sampling periods, estimated density was highest in February (257.6 fish $1000 \mathrm{~m}^{-2}$ ) and lowest in December $\left(60.9\right.$ fish $\left.1000 \mathrm{~m}^{-2}\right)$. Biomass followed the same pattern with a maximum in February

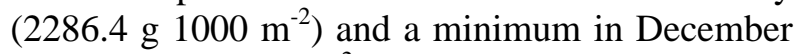
$\left(\begin{array}{llll}366.8 & \mathrm{~g} & 1000 \mathrm{~m}^{-2}\end{array}\right)$. The following species occurred during the sampling period, some of them being occasional (oc) while the others can be classified as permanent residents (rd) and transients (tr): Atherinella brasiliensis - oc (PV) [Atherinidae]; Porychthis porosissimus - oc (SR) [Batrachoididae]; Hypleurochilus fissicornis - rd (PV), Parablennius pilicornis - rd (PV, SR), Scartella aff. cristata - rd (PV, SR) [Blenniidae]; Eucinostomus gula - oc (PV), Eucinostomus melanopterus - oc (PV) [Gerreidae]; Gobiesox barbatulus - rd (PV, SR) [Gobiesocidae]; Bathygobius soporator - rd (PV, SR) [Gobiidae]; Labrisomus nuchipinnis - $\mathrm{rd}$ (PV, SR) [Labrisomidae]; Mugil curema - oc (PV), Mugil platanus - oc (PV) [Mugilidae]; Abudefduf saxatilis - tr (PV, SR), Stegastes fuscus - oc (PV, SR) [Pomacentridae]; Pomatomus saltatrix - oc (PV, SR) [Pomatomidae]; Epinephelus marginatus - tr (PV, SR), Mycteroperca acutirostris - oc (PV) [Serranidae]; Diplodus argenteus - tr (PV, SR) [Sparidae] and Sphoeroides testudineus - oc (PV) [Tetraodontidae]. The fish communities of PV and SR were dominated by Abudefduf saxatilis and by Bathygobius soporator, both in terms of number of individuals and in biomass. 
Table 1 - Number of individuals obtained in Praia Vermelha, SC, Brazil (month/year).

\begin{tabular}{|c|c|c|c|c|c|c|c|c|c|c|c|c|c|c|c|}
\hline Dates & $4 / 98$ & $5 / 98$ & $6 / 98$ & $7 / 98$ & $8 / 98$ & $9 / 98$ & $10 / 98$ & $11 / 98$ & $12 / 98$ & $1 / 99$ & 2/99 & $3 / 99$ & $4 / 99$ & $5 / 99$ & Total \\
\hline $\begin{array}{l}\text { Abudefduf saxatilis } \\
\text { Atherinella } \\
\text { brasiliensis }\end{array}$ & 29 & 35 & 2 & 7 & 20 & 70 & 2 & 1 & 107 & $\begin{array}{r}162 \\
3\end{array}$ & 32 & 105 & 42 & 37 & $\begin{array}{r}651 \\
3\end{array}$ \\
\hline $\begin{array}{l}\text { Bathygobius } \\
\text { soporator }\end{array}$ & 17 & 67 & 16 & & 5 & 23 & 20 & 14 & 33 & 16 & 18 & 26 & 11 & 5 & 271 \\
\hline Diplodus argenteus & & 1 & & 8 & 24 & 18 & & 2 & 1 & & & 4 & & & 58 \\
\hline $\begin{array}{l}\text { Epinephelus } \\
\text { marginatus }\end{array}$ & 4 & 3 & 3 & & & & & & 3 & & 14 & 10 & & & 37 \\
\hline Eucinostomus gula & & & & & & & & & & & 1 & & & & 1 \\
\hline $\begin{array}{l}\text { Eucinostomus } \\
\text { melanopterus }\end{array}$ & & & & & & & & & & & 1 & 2 & & & 3 \\
\hline $\begin{array}{l}\text { Gobiesox barbatulus } \\
\text { Hypleurochilus } \\
\text { fissicornis }\end{array}$ & 14 & 15 & 28 & 5 & 7 & 10 & 6 & 1 & 2 & 1 & 1 & $\begin{array}{l}7 \\
1\end{array}$ & 7 & 3 & $\begin{array}{r}107 \\
1\end{array}$ \\
\hline $\begin{array}{l}\text { Labrisomus } \\
\text { nuchipinnis }\end{array}$ & 11 & 8 & 7 & 5 & 10 & 1 & & & 1 & 1 & 2 & 9 & 4 & 1 & 60 \\
\hline Mugil curema & & & & & & 3 & & & & & & 5 & & & 8 \\
\hline Mugil platanus & & & & 1 & & & & & & & & & & & 1 \\
\hline $\begin{array}{l}\text { Mycteroperca } \\
\text { acutirostris }\end{array}$ & 2 & & & & & & & & & & & & & & 2 \\
\hline $\begin{array}{l}\text { Parablennius } \\
\text { pilicornis }\end{array}$ & 4 & 7 & 4 & 3 & 8 & 8 & 8 & 1 & 3 & 8 & 6 & 1 & 1 & & 62 \\
\hline Pomatomus saltatrix & & & & & & & & & & & & & 1 & 1 & 2 \\
\hline Scartella aff. cristata & & & & & & & & & & & & 1 & 1 & 4 & 6 \\
\hline Sphoeroides nephelus & & & & & & & & & & & & 1 & & & 1 \\
\hline Stegastes fuscus & & & & & & & & & 1 & 4 & 7 & 1 & & & 13 \\
\hline Total & 81 & 136 & 60 & 29 & 74 & 133 & 36 & 19 & 151 & 195 & 82 & 173 & 67 & 51 & 1287 \\
\hline
\end{tabular}

Table 2 - Number of individuals obtained in São Roque, SC, Brazil (month/year).

\begin{tabular}{|c|c|c|c|c|c|c|c|c|c|c|c|c|c|}
\hline Dates & $4 / 98$ & $5 / 98$ & $7 / 98$ & $8 / 98$ & $10 / 98$ & $11 / 98$ & $12 / 98$ & $1 / 99$ & $2 / 99$ & $3 / 99$ & $4 / 99$ & $5 / 99$ & TOTAL \\
\hline Abudefduf saxatilis & 16 & 6 & 3 & & 3 & 17 & 56 & 45 & 66 & 53 & 19 & 22 & 306 \\
\hline Bathygobius & 45 & 25 & 6 & 2 & 4 & 7 & 15 & 6 & 11 & 13 & 8 & 8 & 150 \\
\hline soporator & & & & & & & & & & & & & \\
\hline Diplodus argenteus & & & & & & & & & & & & 2 & 2 \\
\hline $\begin{array}{l}\text { Epinephelus } \\
\text { marginatus }\end{array}$ & 5 & & & 1 & & & & 2 & 8 & 8 & & & 24 \\
\hline Gobiesox barbatulus & 3 & & 1 & 5 & 4 & 1 & 2 & 1 & & 1 & 1 & & 19 \\
\hline $\begin{array}{l}\text { Labrisomus } \\
\text { nuchipinnis }\end{array}$ & 1 & & & 3 & & & & 1 & 3 & 3 & 11 & 3 & 25 \\
\hline $\begin{array}{l}\text { Parablennius } \\
\text { pilicornis }\end{array}$ & & 3 & 5 & 3 & 2 & 1 & & 2 & 2 & 2 & & & 20 \\
\hline Pomatomus saltatrix & & & & & & & & & & & & 1 & 1 \\
\hline $\begin{array}{l}\text { Porychthys } \\
\text { porosissimus }\end{array}$ & & & & & & & & 1 & & & & & 1 \\
\hline Scartella aff. cristata & & & & & & & & & & & & 2 & 2 \\
\hline Stegastes fuscus & & & & & & & & 3 & & & & & 3 \\
\hline Total & 70 & 34 & 15 & 14 & 13 & 26 & 73 & 61 & 90 & 80 & 39 & 38 & 553 \\
\hline
\end{tabular}




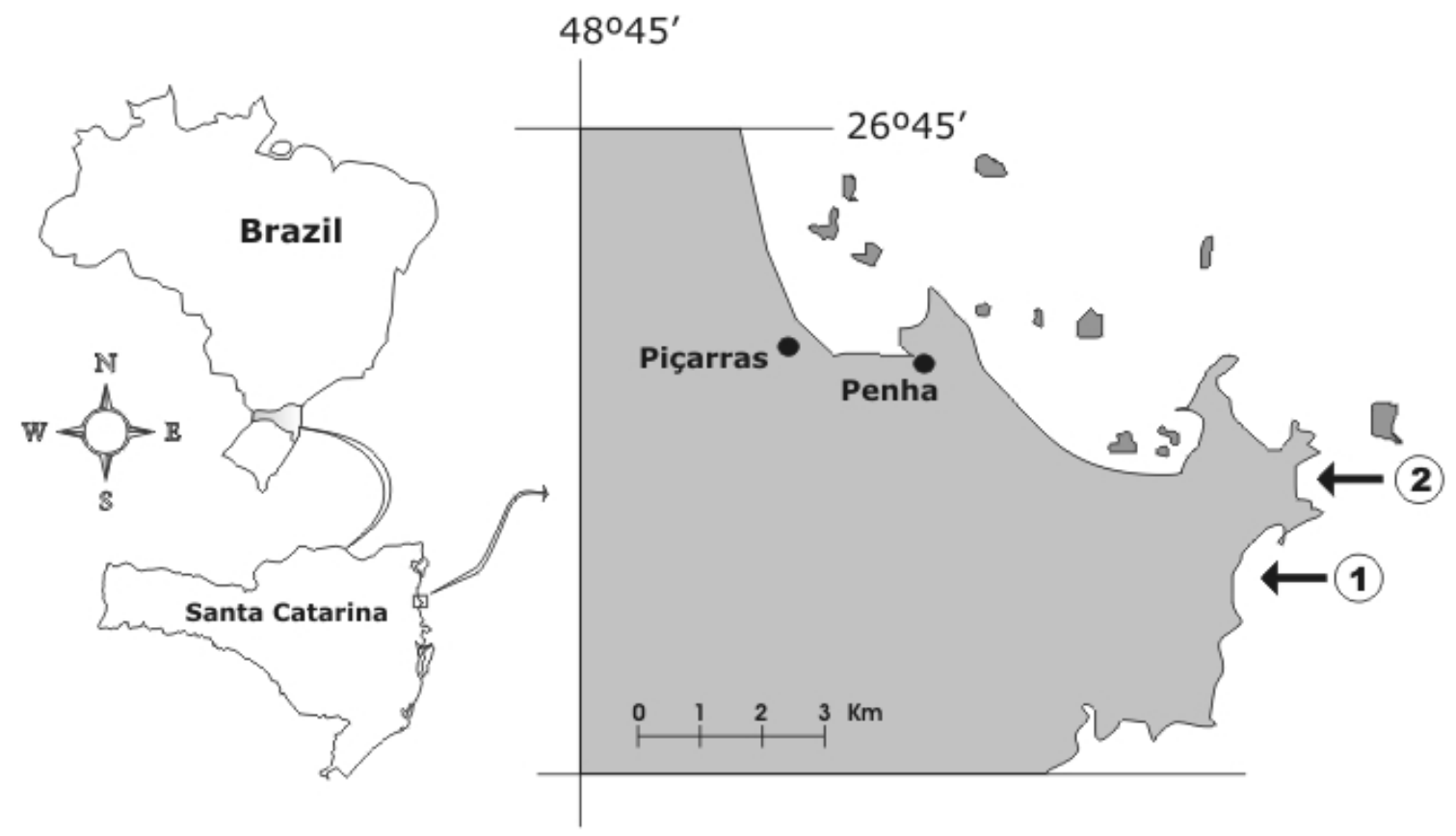

Figure 1 - Location of sampled tide pools, Santa Catarina, Brazil. 1 - Praia Vermelha (PV); 2 - São Roque (SR)

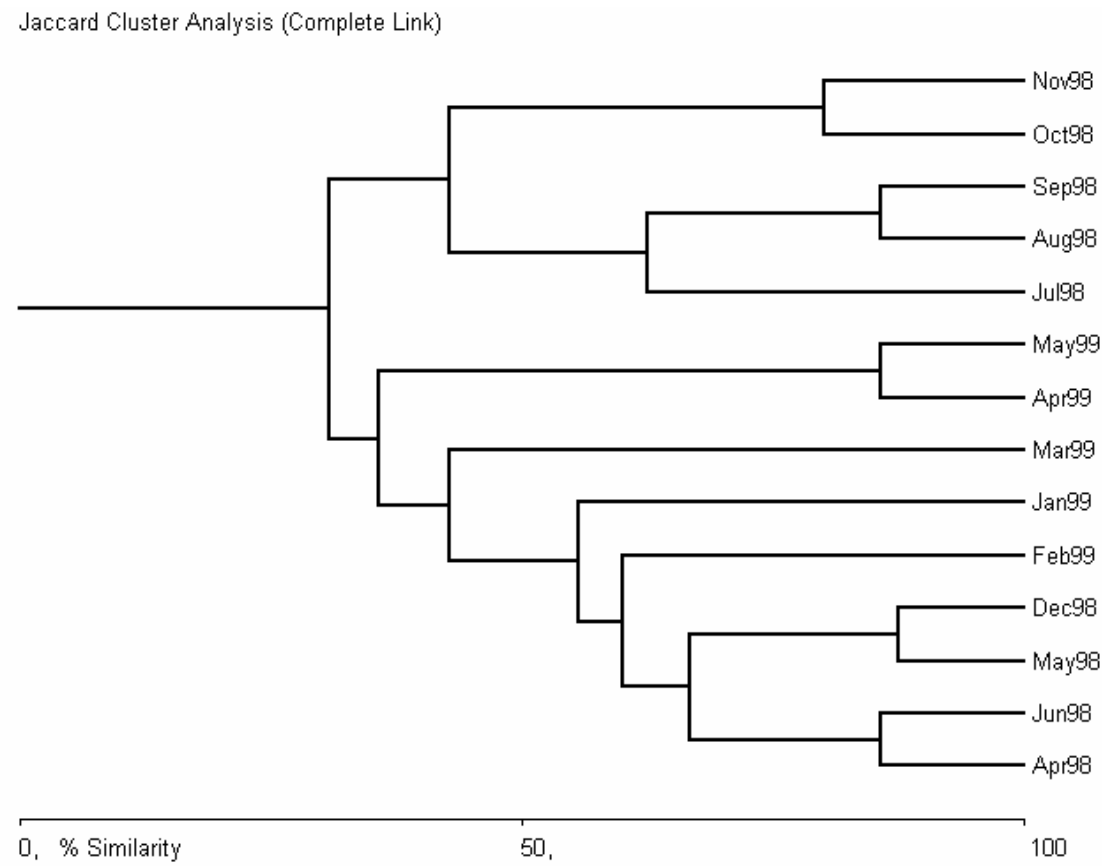

Figure 2 - Percent similarity (Jaccard) between samples from PV. 


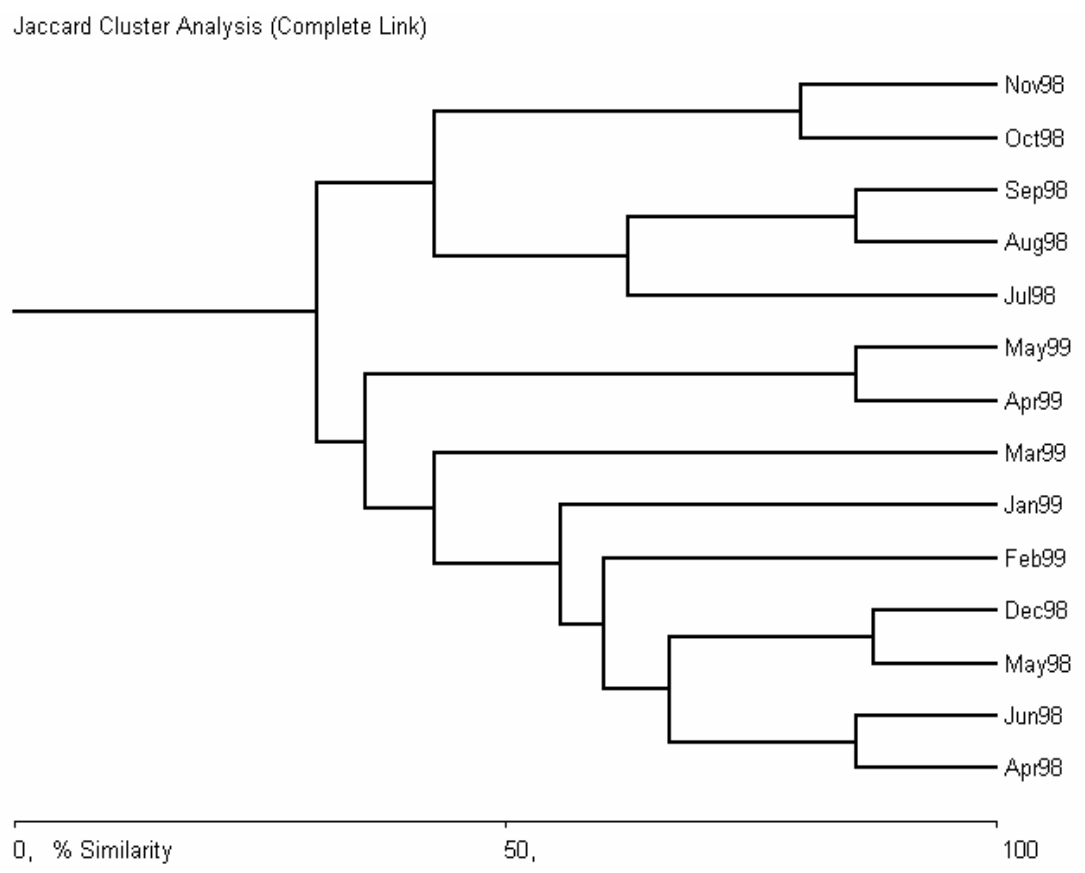

Figure 3 - Percent similarity (Jaccard) between samples from SR.

In PV, A. saxatilis and B. soporator corresponded to $71.7 \%$ of total number of fish and $75.4 \%$ of total biomass. In SR these same species corresponded to $82.4 \%$ of total number and $72.8 \%$ of total biomass. However, there were changes in the guild of dominant species throughout the study (see below). The number of individuals showed a positive correlation between the two sites $\left(r_{\mathrm{s}}=0.685, \mathrm{p}=0.014\right)$.

Table 3 - Number of species (Sp.) and rarefaction curve $\mathrm{E}\left(\mathrm{S}_{50}\right)$ for the samples from PV.

\begin{tabular}{l|r|r}
\multicolumn{1}{c}{ Dates } & Sp. & E[S $\left.\mathbf{S}_{\mathbf{5 0}}\right]$ \\
\hline April 98 & 7 & 6.83 \\
May 98 & 7 & 6.73 \\
June 98 & 6 & 5.98 \\
July 98 & 6 & 1.00 \\
August 98 & 6 & 6.00 \\
September 98 & 7 & 6.75 \\
October 98 & 4 & 1.00 \\
November 98 & 5 & 1.00 \\
December 98 & 8 & 8.00 \\
January 99 & 7 & 6.54 \\
February 99 & 9 & 7.72 \\
March 99 & 13 & 12.35 \\
April 99 & 7 & 6.28 \\
May 99 & 6 & 6.00 \\
Total & 18 & 17.89 \\
\hline
\end{tabular}

\section{Number of Species}

In all samples, number of species in PV varied between 4 (October 1998) and 13 (March 1999) and in SR between 3 (May and December 1998) and 8 (January 1999). The rarefaction curve showed some affinity with the observed number of species in both sites (Tables 3 and 4), and indicated higher richness in Summer months.

Table 4 - Number of species (Sp.) and rarefaction curve $\mathrm{E}\left(\mathrm{S}_{50}\right)$ for the samples from SR.

\begin{tabular}{l|r|r}
\hline \multicolumn{1}{c}{ Dates } & Sp. & $\mathbf{E}\left[\mathbf{S}_{\mathbf{5 0}}\right]$ \\
\hline April 98 & 5 & 4.71 \\
May 98 & 3 & 1.00 \\
July 98 & 4 & 1.00 \\
August 98 & 5 & 1.00 \\
October 98 & 4 & 1.00 \\
November 98 & 4 & 1.00 \\
December 98 & 3 & 2.91 \\
January 99 & 8 & 7.46 \\
February 99 & 5 & 4.74 \\
March 99 & 6 & 5.46 \\
April 99 & 4 & 1.00 \\
May 99 & 6 & 1.00 \\
Total & 11 & 10.97 \\
\hline
\end{tabular}


The rarefaction curve showed clearly that PV had a higher richness that was significantly different from SR $(z=2.214 ; p=0.027)$.

\section{Seasonality}

Total number of individuals and number of species showed a significant correlation (respectively: $\mathrm{r}_{\mathrm{s}}=$ $0.652 ; \mathrm{p}<0.01$ and $\left.\mathrm{r}_{\mathrm{s}}=0.652 ; \mathrm{p}=0.011\right)$ with temperature in PV. In SR, the number of individuals was positively correlated with temperature $\left(\mathrm{r}_{\mathrm{s}}=0.935 ; \mathrm{p}<0.01\right)$. The abundance of $B$. soporator was positively correlated with temperature in PV and in SR (respectively: $\mathrm{r}_{\mathrm{s}}=$ $0.629 ; \mathrm{p}=0.016$ and $\mathrm{r}_{\mathrm{s}}=0.679 ; \mathrm{p}=0.015$ ). The abundance of $A$. saxatilis only showed a significant correlation with temperature in $\mathrm{SR}\left(\mathrm{r}_{\mathrm{s}}=\right.$ 0.834; $\mathrm{p}<0.01$ ). In PV, we also detected a positive correlation between the number of $E$. marginatus and temperature $\left(\mathrm{r}_{\mathrm{s}}=0.751 ; \mathrm{p}<0.01\right)$. However, this species did not occur in seven samples, and we attribute this fact to a recruitment period (see discussion). It was also important to note that both $A$. saxatilis and E. marginatus showed a positive correlation between the two sites (respectively: $r_{\mathrm{s}}=0.676, \mathrm{p}=0.016$ and $\mathrm{r}_{\mathrm{s}}=$ $0.642, \mathrm{p}=0.024)$.

\section{Species Diversity (H')}

In PV, diversity was low $(<1.8)$ throughout the sampling period and did not correlate with temperature ( $p>0.05)$. In SR however, diversity is still low $(<1.6)$ but negatively correlated with temperature $\left(\mathrm{r}_{\mathrm{s}}=-0.621 ; \mathrm{p}=0.031\right)$.

\section{Evenness (J')}

Evenness was generally moderate (>0.4) both in $\mathrm{PV}$ and in SR. In PV, evenness did not correlate with temperature but showed a negative correlation with this parameter in SR $\left(r_{s}=-0.811\right.$; $\mathrm{p}<0.01$ ), and a positive correlation between the two sites $\left(\mathrm{r}_{\mathrm{s}}=0.615 ; \mathrm{p}=0.030\right)$.

\section{Percent Similarity}

Similarity between samples indicated two major clusters for both sites: summer/autumn and winter/spring (\% similarity > 50\%) with adjacent samples showing a tendency to be more clustered (\% similarity $>80 \%$ ) within each group (Figs. 2 and 3 ).

\section{Fish Species}

At both sites A. saxatilis was the dominant species. In PV, it corresponded to $50.6 \%$ of total fish caught and $40.1 \%$ in SR. Tables 5 and 6 present the numerically dominant species for each month in both sites.

As seen above, A. saxatilis was particularly abundant in summer and autumn months. The average total length (TL) of $A$. saxatilis was negatively and significantly correlated with temperature $\left(\mathrm{r}_{\mathrm{s}}=-0.685 ; \mathrm{p}<0.01\right)$ showing that the large numbers of individuals recruited in summer months were small sized juveniles. It is also noticeable the important occurrence of Diplodus argenteus in PV during winter months.

Table 5 - Dominant species in PV for each sample.

\begin{tabular}{|c|c|c|}
\hline Dates & Species & $\%$ \\
\hline April 98 & Abudefduf saxatilis & 35.8 \\
\hline May 98 & Bathygobius soporator & 49.3 \\
\hline June 98 & Gobiesox barbatulus & 46.7 \\
\hline July 98 & Dilodus argenteus & 27.6 \\
\hline August 98 & Diplodus argenteus & 32.4 \\
\hline September 98 & Abudefduf saxatilis & 52.6 \\
\hline October 98 & Bathygobius soporator & 55.6 \\
\hline November 98 & Bathygobius soporator & 73.7 \\
\hline December 98 & Abudefduf saxatilis & 70.8 \\
\hline January 99 & Abudefduf saxatilis & 83.1 \\
\hline February 99 & Abudefduf saxatilis & 39.0 \\
\hline March 99 & Abudefduf saxatilis & 60.7 \\
\hline April 99 & Abudefduf saxatilis & 62.7 \\
\hline May 99 & Abudefduf saxatilis & 72.6 \\
\hline
\end{tabular}


Table 6 - Dominant species in SR for each sample.

\begin{tabular}{|c|c|c|}
\hline Dates & Espécies & $\%$ \\
\hline April 98 & Bathygobius soporator & 64.3 \\
\hline May 98 & Bathygobius soporator & 73.5 \\
\hline July 98 & Bathygobius soporator & 40.0 \\
\hline August 98 & Gobiesox barbatulus & 35.7 \\
\hline October 98 & Bathygobius soporator & 30.8 \\
\hline November 98 & Abudefduf saxatilis & 65.4 \\
\hline December 98 & Abudefduf saxatilis & 76.7 \\
\hline January 99 & Abudefduf saxatilis & 73.7 \\
\hline February 99 & Abudefduf saxatilis & 73.3 \\
\hline March 99 & Abudefduf saxatilis & 66.3 \\
\hline April 99 & Abudefduf saxatilis & 48.7 \\
\hline May 99 & Abudefduf saxatilis & 57.9 \\
\hline
\end{tabular}

\section{DISCUSSION}

When comparing both sites, the pool nearer to the subtidal was significantly richer. Both number of species and number of individuals are commonly higher in pools located nearer to the subtidal (Zander et al., 1999). This is mainly due to the fact that mesotidal pools are poorer in oxygen and sustain higher evaporation rates (Martin and Bridges, 1999). According to Mahon and Mahon (1994), bigger pools have more fish, and pool size is a plausible reason for the differences verified between the two pools studied (Nieder, 1993). Occasional visitors also occurred especially in PV and not in SR. This is typical of subtidal proximity since the contact between the two habitats is greater and causes significant intrusions of opportunistic species (Ojeda and Dearborn, 1991; Deady and Fives, 1995). Both pools showed an effect of seasonality in the abundance of fish. This was expected in regions, such as Santa Catarina's littoral, where productivity determined the abundance and recruitment of fish (Grossman, 1982; Prochazka and Griffiths, 1992). In some extreme cases, winter conditions may lead to a total absence of fish in tidepools (Moring, 1990). The number of species obtained in this study (19 in $\mathrm{PV} ; 11$ in SR) was comparable to that obtained from other locations from temperate regions in the Atlantic: 13 in Roscoff, France (Gibson, 1972); 12 in the W coast of England (Jones and Clare, 1977); 17 to 12 in False Bay and W Cape, S. Africa (Bennett and Griffiths, 1984) and 13 in Feteira, Azores (Santos et al., 1994). However, three tidal pools from the tropical Atlantic: Barbados - 62 species (Mahon and Mahon, 1994), Cabo Branco, NE Brazil - 42 species (Rosa et al., 1997) and Manguinhos SE Brazil - 35 species (Zamprogno,
1989) show a significantly higher number of species, which is related to their greater size. Nevertheless, both diversity $\left(H^{\prime}\right)$ and evenness $\left(J^{\prime}\right)$ are very similar between these same sites. Many authors have related the importance of families such as Blenniidae, Gobiidae and Gobiesocidae as dominant groups in intertidal pools, as they belong to groups that were good examples of adaptation, from distinct evolutionary lines, to these habitats, especially in warm and temperate latitudes (Arruda, 1990; Santos et al., 1994). Some of our dominant species (Bathygobius soporator and Parablennius pilicornis) were also important in other rock pools from NE Brazil (Rosa et al., 1997), and B. soporator, Scartella aff. cristata and Labrisomus nuchipinnis dominate tidepools in SE Brazil (Zamprogno, 1989). From the transient species, both Abudefduf saxatilis and Diplodus argenteus are known to occur in tidepools, although they recruit on different seasons, being the former in summer and the latter in winter. In this way, there is less competition since these two transient species often show considerable diet overlap (Allen, 1991; Cervigón, 1993).

One particularly important aspect of this study was the recruitment of juvenile dusky groupers (Epinephelus marginatus) to the pools in late summer. The importance of this species for fisheries in southern Brazil is widely recognised (Branco et al., 1999). However its ecology is still poorly known. A recent study (Bertoncini et al., 2003) showed that Santa Catarina's groupers have a reproductive period peak in early summer. Postlarvae then recruit to tidepools after completing a period of planktonic life. Although this is known for other areas of the grouper's distribution (Azevedo et al., 1995; Barreiros, 1998), their occurrence in Santa Catarina's tidepools is 
reported here for the first time and constitutes an important input for the knowledge of their ontogenic distribution and overall ecology.

In conclusion, both pools were characterised by richness, diversity and evenness values similar to those found in similar environments from the Atlantic. They were clearly dominated by typical resident species, namely Bathygobius soporator, Parablennius pilicornis, Labrisomus nuchipinnis and Gobiesox barbatulus, although there was a very high importance of juveniles from transient species, especially from Abudefduf saxatilis and, to a lesser extent, from Epinephelus marginatus. Both these species recruited to the pools as juveniles where they lived for a short but very important period of their ontogeny. Resident species that dominated tide pools do not occur, or were seldom found, in adjacent subtidal reefs (see Floeter et al., 2001). Thus, their conservation could be totally linked to the preservation of these habitats that are scarce in Santa Catarina. The fish community was stable throughout the year and this could be due to the stabilising effect of residents.

\section{ACKNOWLEDGMENTS}

Thanks are due to Fábio Lopes, Felippe Daros, Gabriel Lima, Isabel Tancredi, João Silva and Valdenir Inez of the Universidade do Vale do Itajaí who made collections possible. Travels and stays of JPB in Brazil were supported by the Programa PRODEP and by kind courtesy of the CTTMar/UNIVALI.

\section{RESUMO}

Este trabalho realizou-se entre Abril de 1998 e Maio de 1999 e visou o estudo das comunidades de peixes em duas poças de maré situadas nas praias de Praia Vermelha (PV) e São Roque (SR), Santa Catarina, Brasil. A poça de PV é maior e mais próxima do sub-mareal. Os exemplares foram coletados mensalmente, durante a baixa-mar, com o anestésico quinaldina. Em PV recolheram-se 1287 peixes pertencentes a 19 espécies enquanto que em SR foram capturados 553 peixes de 11 species. Em ambas as poças as espécies dominantes foram Bathygobius soporator (Gobiidae), Abudefduf saxatilis (Pomacentridae), Parablennius pilicornis (Blenniidae), Labrisomus nuchipinnis (Labrisomidae) e Epinephelus marginatus (Serranidae). A diversidade e o número de peixes foram maiores nos meses de Verão e correspondem a uma época de recrutamento para as espécies $A$. saxatilis e $E$. marginatus.

\section{REFERENCES}

Allen, G. R. (1991), Damselfishes of the World. Melle, Germany : Mergus Publishers. 271 pp.

Almeida, V. G. (1973), New records of tidepool fishes from Brazil. Papéis Avulsos Zool., 26 : (14), 187-191.

Almeida, V. G. (1983), Levantamento da ictiofauna de poças de maré de Salvador e adjacências. Parte I Osteichthyes - Anguilliformes. Natura, 83 : (5), 94-109.

Arruda, L. M. (1979), Specific composition and relative abundance of intertidal fish at two places on the Portuguese coast (Sesimbra and Magoito, 1977-78). Arq. Mus. Bocage, 6, 325-342.

Arruda, L. M. (1990), Population structures of fish in the intertidal ranges of Portuguese coasts. Vie Mill., 40 : (4), 319-323.

Azevedo, J. M. N.; Rodrigues, J. B.; Mendizabal, M. and Arruda, L. M. (1995), Study of a sample of dusky groupers, Epinephelus marginatus (Lowe, 1834), caught in a tide pool at Lajes do Pico, Azores. Bol. Mus. Mun. Funchal, 4 : (suppl.), 55-64.

Barreiros, J. P. (1998), Inversão sexual em Epinephelus marginatus (Lowe, 1834) (Pisces: Serranidae, Epinephelinae) nos Açores. Rev. Port. Zoot., 5 : (1), 81-90.

Beja, P. R. (1995), Structure and seasonal fluctuations of rocky littoral fish assemblages in south-western Portugal: implications for otter prey availability. J. Mar. Biol. Ass. U. K., 75 : (4), 833-847.

Bennett, B. A. and Griffiths, C. L. (1984), Factors affecting the distribution, abundance and diversity of rock-pool fishes on the Cape Peninsula, South Africa. S. Af. J. Zool., 19, 97-104.

Bertoncini, A.; Machado, L.; Hostim-Silva, M. and Barreiros, J. P. (2003), Reproductive biology of the dusky grouper Epinephelus marginatus (Lowe, 1834) (Perciformes: Serranidae, Epinephelinae) in Santa Catarina, Brazil. Braz. Arch. Biol. Tech., 46 : (1), [in press].

Branco, E. J.; Rebelo, S. and Almeida, R. F. (1999), Informe de pesca extrativista marinha em Santa Catarina, 1997. IBAMA CEPSUL. 37 pp.

Cervigón, F. R. (1993), Los Peces Marinos de Venezuela. Caracas, Venezuela : Fundación Científica Los Roques, v. 2. pp. 497.

Crabtree, R. E. and Dean, J. M. (1982), The structure of two South Carolina estuarine tidal pool fish assemblages. Estuaries, 5 : (1), 2-9. 
Deady, S. and Fives, J. M. (1995), The diet of corkwing wrasse, Crenilabrus melops, in Galway Bay, Ireland and in Dinard, France. J. Mar. Biol. Ass. U. K., 75, 635-649.

Floeter, S. R.; Guimarães, R. Z. P.; Rocha, L. A.; Ferreira, C. E. L.; Rangel, C. A. and Gasparini, J. L. (2001), Geographic variation in reef-fish assemblages along the Brazilian coast. Global Ecol. Biog., 10, 423-431.

Fuji, A. (1988), Measuring wave force on a rocky intertidal shore. Bull. Fac. Fish. Hokkaido Univ., 39 : (4), 257-264.

Gibson, R. N. (1967), The use of the anaesthetic quinaldine in fish ecology. J. Anim. Ecol., 36, 295-301.

Gibson, R. N. (1972), The vertical distribution and feeding relationships of intertidal fish on the Atlantic coast of France. J. Anim. Ecol., 36, 295-301.

Gibson, R. N. (1999), Methods for studying intertidal fishes. In: Horn, M. H.; Martin, K. L. M. and Chotkowski, M. A. (eds.). Intertidal Fishes - Life in Two Worlds. San Diego, USA : Academic Press. pp. 7-25.

Gibson, R. N. and Yoshiyama, R. M. (1999), Intertidal fish communities. In: Horn, M. H.; Martin, K. L. M. and Chotkowski, M. A. (eds.). Intertidal Fishes - Life in Two Worlds. San Diego, USA : Academic Press. pp. 264-296.

Gordon, M. S. (1998), African amphibious fishes and the invasion of land by the tetrapods. S. Afr. J. Zool., 33 : (2), 115-118.

Grossman, G. D. (1982), Dynamics and organization of a rocky intertidal fish assemblage: the persistence and resilience of taxocene structure. Am. Nat., 119 : (5), 611-637.

Jones, D. and Clare, J. (1977), Annual and long-term fluctuations in the abundance of fish species inhabiting an intertidal mussel bed in Morecombe Bay, Lancashire. Zool. J. Linn. Soc., 60, 117-172.

Ludwig, J. A. and Reynolds, J. F. (1988), Statistical Ecology - A Primer on Methods and Computing. John Wiley and Sons, NY. xviii $+337 \mathrm{pp}$.

Magurran, A. E. (1988), Ecological Diversity and its Measurement. Australia : Croom Helm. x + 179pp.

Mahon, R. and Mahon, S. D. (1994), Structure and resilience of a tidepool fish assemblage at Barbados. Env. Biol. Fish., 41, 171-190.

Martin, K. L. M. and Bridges, C. R. (1999), Respiration in water and air. In: Horn, M. H.; Martin, K. L. M. and Chotkowski, M. A. (eds.). Intertidal Fishes - Life in Two Worlds. San Diego, USA : Academic Press. pp. 54-78.

Moring, J. R. (1990), Seasonal absence of fishes in tidepools of a boreal environment (Maine, USA). Hydrobiol., 194, 163-168.

Nieder, J. (1993), Distribution of juvenile blennies (Pisces, Blenniidae) in small-tide pools: result of low tide lottery or strategic habitat selection? Bonn. Zool. Beit., 44 : (3-4), 133-140.
Ojeda, F. P. and Dearborn, J. H. (1991), Feeding ecology of benthic mobile predators: Experimental analyses of their influence in rocky subtidal communities of the Gulf of Maine. J. Exp. Mar. Biol. Ecol., 149 : (1), 13-44.

Pielou, E. C. (1977), Mathematical Ecology. Wiley, NY. 385 pp.

Prochazka, K. (1996), Seasonal patterns in a temperate intertidal fish community on the west coast of South Africa. Env. Biol. Fish., 45, 133-140.

Prochazka, K. and Griffiths, C. L. (1992), The intertidal fish fauna of the west coast of South Africa - species, community and biogeographic patterns. S. Af. J. Zool., 27 : (3), 115-120.

Prochazka, K.; Chotkowski, M. A. and Buth, D. G. (1999), Biogeography of rocky intertidal fishes. In: Horn, M. H.; Martin, K. L. M. and Chotkowski, M. A. (eds.). Intertidal Fishes - Life in Two Worlds. San Diego, USA : Academic Press. pp. 332-355.

Rosa, R. S.; Rosa, I. L. and Rocha, L. A. (1997), Diversidade da ictiofauna de poças de maré da praia do Cabo Branco, João Pessoa, Paraíba, Brasil. Rev. Bras. Zool., 14 : (1), 201-212.

Rangueley, R. W. and Kramer, D. L. (1995), Tidal effects on habitat selection and aggregation by juvenile pollock Polachius virens in the rocky intertidal zone. Mar. Ecol. Prog. Ser., 126 : (1-3), 19-29.

Santos, R. S.; Nash, R. D. M. and Hawkins, S. J. (1994), Fish assemblages on intertidal shores of the island of Faial, Azores. Arquipélago-Life Mar. Sci., 12A, 87-100.

Willis, T. J. and Roberts, C. D. (1996), Recolonization and recruitment of fishes to intertidal rockpools at Wellington, New Zealand. Env. Biol. Fish., 47, 329-343.

Zacharias, M. A. and J. C. Roff (2001), Explanations of patterns of intertidal diversity at regional scales. $J$. Biog., 28, 471-483.

Zamprogno, C. (1989), Distribuição e hábitos alimentares de peixes na zona entremarés de recifes rochosos da praia de Manguinhos, Espírito Santo. Universidade Estadual de Campinas, SP, Tese de Mestrado. $171 \mathrm{pp}$.

Zander, C. D. J.; Nieder, J. and Martin, K. L. M. (1999), Vertical distribution patterns. In: Horn, M. H.; Martin, K. L. M. and Chotkowski, M. A. (eds.). Intertidal Fishes - Life in Two Worlds. San Diego, USA : Academic Press. pp. 26-53.

Received: May 20, 2002; Revised: September 24, 2002; Accepted: May 12, 2003. 